\title{
Studies with live attenuated influenza virus in chronic bronchitis
}

\author{
I. G. WINSON, J. M. SMIT'1, C. W. POTTER, AND P. HOWARD
}

From the Departments of Medicine and Virology, University of Sheffield, The Royal Hospital, Sheffield S1 3SR, UK

\author{
Winson, I. G., Smit, J. M., Potter, C. W., and Howard, P. (1977). Thorax, 32, 726-728. Studies with \\ live attenuated influenza virus in chronic bronchitis. The use of a live, recombinant virus for \\ immunisation against influenza produced a number of respiratory illnesses, some severe, in patients \\ with chronic obstructive airways disease. These patients are probably more susceptible to the \\ influenza virus than are normal subjects. Special care will be needed in testing these viruses on \\ patients with respiratory disease.
}

Live, recombinant viruses are at present under investigation for immunisation against influenza, since these vaccines may be more acceptable to the public and have been reported to produce a more solid immunity than inactivated virus vaccines (Beare et al., 1968). A number of candidate vaccine strains have been tested in normal persons with few side effects (Beare et al., 1975; Morris et al., 1975). Influenza infection is particularly severe and has a high mortality in patients with chronic bronchitis and emphysema. It was thought necessary, therefore, that the effects of influenza viruses should be tested independently in these patients, since these subjects may produce reactions to virus infection which were not detectable in normal volunteers.

\section{Patients and methods}

Nineteen patients attending a bronchitis clinic volunteered to be immunised with a live recombinant influenza virus; all had sputum expectoration which would classify them as chronic bronchitics according to the Medical Research Council questionnaire on respiratory symptoms (1960), all had moderate or severe airways obstruction, and most were receiving theophylline or salbutamol bronchodilatation and courses of antibiotics as dictated by infective chest illnesses. None of the volunteers was receiving corticosteroids, but all had breathlessness which limited them to walking at their own pace on the level or more severe disability.

Influenza virus $\mathbf{A} /$ Victoria/75/4a2, a recombinant of influenza viruses $\mathrm{A} / \mathrm{Victoria} / 75$ (H3N2) and

'Elective student, University of Groningen, Holland
A/PR/8/34 (HON1), was obtained from Dr. A. S. 궈 Beare, Common Cold Research Unit, Harvard 0 Hospital, Salisbury; volunteers lay on an examination couch with the head hyperextended, and $10^{7 \cdot 0}$ EID $_{50}$ of virus in an $0.5 \mathrm{ml}$ volume was inoculated intranasally by drops. After inoculation the volunteers $\frac{\varnothing}{\square}$ remained lying for a minute. Blood samples were $\underset{F}{\Rightarrow}$ collected before and three weeks after virus inocula- $\frac{3}{3}$ tion, and evidence of infection was obtained by the demonstration of a four-fold increase in serum haemagglutination-inhibiting (HI) antibody following virus inoculation; volunteers not showing an antibody response were used as controls for infected subjects.

The forced expiratory volume $\left(\mathrm{FEV}_{1 \cdot 0}\right)$, the forced 3 . vital capacity (FVC), and flow volume curve were $\delta$ recorded for each volunteer using a Monoghan spirometer on days 0,7 , and 21 after virus inoculation. Ono day 0 a clinical history of respiratory symptoms was recorded and a further symptom record was obtained on days $2-3,7,14$, and 21 . Symptoms were graded $0-4$. as shown in Table 1.

\section{Results}

Serological evidence of infection with A/Victoria/75 $4 \mathrm{a} 2$ virus was obtained for 10 of the 19 volunteers; no such evidence of infection was obtained for theof remaining nine volunteers and these are used as controls. The baseline respiratory function data of all patients, divided into test and control groups, are $\stackrel{\odot}{\circ}$ shown in Table 2, together with the results obtained $\frac{\text { }}{\mathbb{D}}$ on days 7 and 21 . No significant changes were seen $\frac{2}{2}$ at 7 and 21 days for 15 of the patients; two infected 
Table 1 Grading

\begin{tabular}{ll}
\hline 0 & No symptoms \\
1 & Mild, upper respiratory infection with coryza and sore throat \\
2 & $\begin{array}{l}\text { Moderate upper respiratory infection with coryza, headache, } \\
\text { sore throat, and cough }\end{array}$ \\
3 & $\begin{array}{l}\text { Lower respiratory infection with breathlessness increased } \\
\text { and/or change in sputum production }\end{array}$ \\
4 & $\begin{array}{l}\text { Admission to hospital } \\
\end{array}$
\end{tabular}

Table 2 Pulmonary function data of patients given influenza vaccine

\begin{tabular}{|c|c|c|c|c|c|c|c|}
\hline \multirow{2}{*}{$\begin{array}{l}\text { Virus } \\
\text { infection } \\
\text { (serology) }\end{array}$} & \multirow[b]{2}{*}{ Patient } & \multicolumn{2}{|l|}{ Day 0} & \multicolumn{2}{|l|}{ Day 7} & \multicolumn{2}{|c|}{ Day 21} \\
\hline & & $\begin{array}{l}F E V_{1} \\
(l)\end{array}$ & $\begin{array}{l}F V C \\
(l)\end{array}$ & $\begin{array}{l}F E V_{1} \\
(l)\end{array}$ & $\begin{array}{l}F V C \\
(l)\end{array}$ & $\begin{array}{l}F E V_{1} \\
(l)\end{array}$ & $\begin{array}{l}F V C \\
(I)\end{array}$ \\
\hline \multirow[t]{2}{*}{ Positive } & $\begin{array}{l}1 \\
2 \\
3 \\
4 \\
5^{*} \\
6 \\
7 \\
8^{*}\end{array}$ & $\begin{array}{l}1 \cdot 15 \\
0 \cdot 44 \\
1 \cdot 27 \\
0 \cdot 36 \\
0 \cdot 47 \\
0 \cdot 97 \\
2 \cdot 23 \\
1 \cdot 17\end{array}$ & $\begin{array}{l}2 \cdot 72 \\
1 \cdot 27 \\
2 \cdot 26 \\
0 \cdot 80 \\
1 \cdot 43 \\
1 \cdot 32 \\
3 \cdot 40 \\
2 \cdot 03\end{array}$ & $\begin{array}{l}1 \cdot 30 \\
0.47 \\
1 \cdot 47 \\
0 \cdot 50 \\
0 \cdot 50 \\
0.91 \\
2 \cdot 02 \\
0.94\end{array}$ & $\begin{array}{l}3 \cdot 32 \\
1 \cdot 74 \\
2 \cdot 54 \\
1 \cdot 02 \\
1 \cdot 80 \\
1 \cdot 89 \\
3 \cdot 16 \\
1 \cdot 40\end{array}$ & $\begin{array}{l}1.07 \\
0.42 \\
1.56 \\
0.48 \\
0.34 \\
0.87 \\
2.04 \\
\text { Admis } \\
\text { to hos! }\end{array}$ & $\begin{array}{l}2 \cdot 50 \\
1 \cdot 43 \\
2 \cdot 62 \\
1 \cdot 48 \\
1 \cdot 28 \\
1 \cdot 83 \\
2.95 \\
\text { ssion } \\
\text { pital }\end{array}$ \\
\hline & $\begin{array}{r}9 \\
10\end{array}$ & $\begin{array}{l}1 \cdot 14 \\
1 \cdot 54\end{array}$ & $\begin{array}{l}3 \cdot 00 \\
3 \cdot 23\end{array}$ & $\begin{array}{l}1 \cdot 15 \\
1 \cdot 81\end{array}$ & $\begin{array}{l}2 \cdot 99 \\
3 \cdot 72\end{array}$ & $\begin{array}{l}1 \cdot 18 \\
1 \cdot 73\end{array}$ & $\begin{array}{l}3 \cdot 10 \\
3 \cdot 62\end{array}$ \\
\hline Negative & $\begin{array}{l}11 \\
12 \\
13 \\
14^{*} \\
15 \\
16 \\
17 \\
18^{*} \\
19\end{array}$ & $\begin{array}{l}0.99 \\
1.80 \\
1.23 \\
1.37 \\
0.92 \\
0.67 \\
2.06 \\
1.33 \\
2.38\end{array}$ & $\begin{array}{l}2 \cdot 48 \\
3 \cdot 01 \\
2 \cdot 12 \\
2 \cdot 43 \\
2 \cdot 62 \\
1 \cdot 59 \\
3 \cdot 76 \\
2 \cdot 59 \\
3 \cdot 79\end{array}$ & $\begin{array}{l}1 \cdot 20 \\
2 \cdot 02 \\
1 \cdot 36 \\
1 \cdot 13 \\
1 \cdot 23 \\
0 \cdot 78 \\
1 \cdot 86 \\
1 \cdot 01 \\
2 \cdot 25\end{array}$ & $\begin{array}{l}3 \cdot 37 \\
3 \cdot 28 \\
2 \cdot 45 \\
2 \cdot 58 \\
3 \cdot 23 \\
1 \cdot 73 \\
3 \cdot 28 \\
1 \cdot 79 \\
3 \cdot 50\end{array}$ & $\begin{array}{l}1.55 \\
1.64 \\
1.51 \\
0.69 \\
1.07 \\
0.52 \\
2.00 \\
0.66 \\
2.77\end{array}$ & $\begin{array}{l}3 \cdot 83 \\
2 \cdot 87 \\
2 \cdot 54 \\
2 \cdot 25 \\
2 \cdot 86 \\
1 \cdot 22 \\
3 \cdot 44 \\
1 \cdot 37 \\
3 \cdot 90\end{array}$ \\
\hline
\end{tabular}

*Substantial fall of respiratory function.

Table 3 Reactions to positive virus infection

\begin{tabular}{|c|c|c|c|c|c|c|c|}
\hline \multirow[b]{2}{*}{ Patient } & \multirow{2}{*}{$\begin{array}{l}\text { Age } \\
(y r)\end{array}$} & \multirow{2}{*}{$\begin{array}{l}\text { Range of } \\
F E V_{1} \\
\text { (l) }\end{array}$} & \multicolumn{4}{|c|}{ Reaction grade on day } & \multirow{2}{*}{$\begin{array}{l}\text { Maximum } \\
\text { value }\end{array}$} \\
\hline & & & $2-3$ & 7 & 14 & 21 & \\
\hline 1 & 65 & $\begin{array}{l}1 \cdot 07-1 \cdot 30 \\
(21) \dagger(7) \dagger\end{array}$ & $\mathbf{0}$ & 3 & 3 & $\mathbf{0}$ & 3 \\
\hline 2 & 70 & $\begin{array}{l}0.42-0 \cdot 47 \\
(21) \quad(7)\end{array}$ & $\mathbf{0}$ & 0 & 3 & 0 & 2 \\
\hline 3 & 80 & $\begin{array}{c}1 \cdot 27-1 \cdot 56 \\
(0)(27)\end{array}$ & $\mathbf{0}$ & 2 & 0 & $\mathbf{0}$ & 2 \\
\hline 4 & 61 & $\begin{array}{c}0.36-0.50 \\
(0) \quad(7)\end{array}$ & $\mathbf{0}$ & 1 & 1 & 0 & 1 \\
\hline 5 & 63 & $\begin{array}{l}0.34-0.50 \\
(27) \quad(7)\end{array}$ & 0 & 2 & 2 & 3 & $4^{*}$ \\
\hline 6 & 74 & $\begin{array}{l}0.87-0.97 \\
(21)(10)\end{array}$ & $\mathbf{0}$ & 3 & 0 & 0 & 2 \\
\hline 7 & 60 & $\begin{array}{c}2 \cdot 02-2 \cdot 23 \\
(7) \quad(0)\end{array}$ & 0 & 1 & 2 & $\mathbf{0}$ & 2 \\
\hline 8 & 63 & $\begin{array}{c}0.94-1 \cdot 17 \\
(7) \quad(0)\end{array}$ & 0 & 3 & 4 & 4 & $4^{*}$ \\
\hline 9 & 66 & $\begin{array}{c}1 \cdot 14-1 \cdot 18 \\
(0)(21)\end{array}$ & 0 & 2 & 1 & 1 & 2 \\
\hline 10 & 60 & $\begin{array}{l}1 \cdot 54-1 \cdot 81 \\
(0) \quad(7)\end{array}$ & 3 & 3 & 3 & $\mathbf{0}$ & 3 \\
\hline
\end{tabular}

*This patient was admitted to hospital.

†The figures in parentheses indicate the day on which the relevant figure occurred. volunteers and two control subjects showed a substantial fall of the FEV $\mathrm{FV}_{1.0}$ after day 0 .

Tables 3 and 4 describe the respiratory symptoms which followed immunisation of the test and control groups. Only one of the infected volunteers had distinct symptoms 2-3 days post-infection, but five complained of severe reactions 7 or 14 days after virus inoculation; two volunteers (Nos 5 and 8 ) continued to have severe symptoms 21 days after infection and had to be admitted to hospital. Of the control subjects (Table 4), two had definite symptoms 2-3 days post-infection, but in both cases these symptoms had disappeared by day 7. Two other patients developed severe respiratory symptoms during the observation period.

Table 5 shows the comparison of the maximum grades of reaction in the two groups of patients. Reaction rates were significantly greater for virusinfected volunteers than for control subjects. Nine of 10 test subjects showed a grade 2 or greater reaction at some time during the observation period.

Table 4 Reactions to negative virus infection

\begin{tabular}{|c|c|c|c|c|c|c|c|}
\hline \multirow[b]{2}{*}{ Patient } & \multirow{2}{*}{$\begin{array}{l}\text { Age } \\
(y r)\end{array}$} & \multirow{2}{*}{$\begin{array}{l}\text { Range of } \\
F E V_{1} \\
(l)\end{array}$} & \multicolumn{4}{|c|}{ Reaction grade on day } & \multirow{2}{*}{$\begin{array}{l}\text { Maximum } \\
\text { value }\end{array}$} \\
\hline & & & $2-3$ & 7 & 14 & 27 & \\
\hline 11 & 67 & $\begin{array}{c}0.99-1 \cdot 55 \\
(0)(7)\end{array}$ & 0 & 3 & 0 & $\mathbf{0}$ & 3 \\
\hline 12 & 64 & $\begin{array}{l}1 \cdot 64-2 \cdot 02 \\
(21) \quad(7)\end{array}$ & 2 & 0 & 0 & 0 & 2 \\
\hline 13 & 52 & $\begin{array}{l}1 \cdot 23-1 \cdot 51 \\
(0)(21)\end{array}$ & 0 & 1 & 1 & 0 & 1 \\
\hline 14 & 59 & $\begin{array}{c}1 \cdot 37-0.69 \\
(0)(21)\end{array}$ & 0 & $\mathbf{0}$ & 0 & 0 & 0 \\
\hline 15 & 60 & $\begin{array}{c}1.23-0.92 \\
(7) \quad(0)\end{array}$ & 0 & 1 & 0 & 0 & 1 \\
\hline 16 & 62 & $\begin{array}{l}0.52-0.78 \\
(21) \quad(7)\end{array}$ & 0 & 2 & 3 & 3 & 3 \\
\hline 17 & 82 & $\begin{array}{c}1 \cdot 86-2 \cdot 06 \\
(7) \quad(0)\end{array}$ & 2 & 1 & 1 & 1 & 2 \\
\hline 18 & 60 & $\begin{array}{c}1 \cdot 33-0.66 \\
(0)(21)\end{array}$ & $\mathbf{0}$ & 2 & 0 & $\mathbf{0}$ & 2 \\
\hline 19 & 45 & $\begin{array}{c}2 \cdot 25-2 \cdot 77 \\
(7)(21)\end{array}$ & $\mathbf{0}$ & 0 & 0 & 0 & 0 \\
\hline
\end{tabular}

Table 5 Comparison of reaction in virus-infected and non-infected patients

\begin{tabular}{|c|c|c|c|c|c|}
\hline \multirow[b]{2}{*}{$\begin{array}{l}\text { Group } \\
\text { Test (virus infected) } \\
\text { Control }\end{array}$} & \multicolumn{5}{|c|}{ Maximum grade of clinical reaction } \\
\hline & $\begin{array}{l}0 \\
0 \\
2\end{array}$ & $\begin{array}{l}1 \\
1 \\
2\end{array}$ & $\begin{array}{l}2 \\
5 \\
3\end{array}$ & $\begin{array}{l}3 \\
2 \\
2\end{array}$ & \\
\hline
\end{tabular}

\section{Discussion}

This present study was made as a preliminary investigation into the use of live influenza virus vaccines for the immunisation of patients with 
chronic bronchitis; it was hoped that information obtained from the inoculation of a few patients would lead to the setting up of a double-blind trial. In the event the reaction rate was so high that we thought the results of the preliminary studies should be reported and for the moment the double-blind trial has been abandoned. The number of respiratory symptoms in patients not showing serological evidence of virus infection was surprising; it is possible that a relatively mild infection may have occurred in these subjects without stimulating a serum antibody response. Of particular importance are the number of reactions observed in the test group and the two severe reactions which occurred. All the severe reactions resolved after active treatment. The symptoms of infected volunteers were most severe after the end of the first week rather than within the expected first few days. Thus influenza viruses which are attenuated for normal subjects may present specific problems to patients with chronic bronchitis; although no immediate symptoms are produced, infection may result in a delayed exacerbation of symptoms.

It is important that investigations into the use of live influenza virus vaccines should continue since they may offer an alternative and possibly improved method of immunisation against influenza. However, the use of results obtained in normal volunteers is relevant only to normal subjects, and virus strains to be used in patients with severe airways obstruction should be tested in similar patients. It is possible that live virus vaccines for use in patients with chronic bronchitis should be more attenuated than is necessary for normal individuals.

Professor Sir Charles Stuart-Harris gave much appreciated help and criticism.

The work was part of the studies undertaken by members of the MRC Committee on influenza and other respiratory virus vaccines-ad hoc group on pulmonary function tests.

\section{References}

Beare, A. S., Hobson, D., Reed, S. E., and Tyrrell, D. A. J. (1968). A comparison of live and killed influenza-virus vaccines. Lancet, 2, 418-420.

Beare, A. S., Schild, G. C., and Craig, J. W. (1975). Trials in man with live recombinants made from $A / P R / 8 / 34$ (H0 N1) and wild H3 N2 influenza viruses. Lancet, 2, 729-734.

Morris, C. A., Freestone, D. S., Stealey, V. M., and Oliver, P. R. (1975). Recombinant WRL 105 strain live attenuated influenza vaccine. Lancet, 2, 196-199.

Requests for reprints to: Dr. P. Howard, Senior Lecturer in Medicine, The Royal Hospital, Sheffield S1 3SR, UK. 